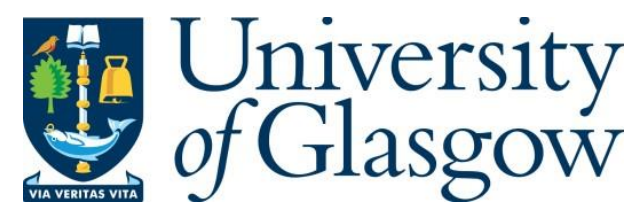

Gray, N. (2018) Beyond the Right to the City: territorial autogestion and the Take over the City movement in 1970s Italy. Antipode: A Radical Journal of Geography, 50(2), pp. 319-339.

There may be differences between this version and the published version. You are advised to consult the publisher's version if you wish to cite from it.

This is the peer reviewed version of the following article Gray, N. (2018) Beyond the Right to the City: territorial autogestion and the Take over the City movement in 1970s Italy. Antipode: A Radical Journal of Geography, 50(2), pp. 319-339, which has been published in final form at http://dx.doi.org/10.1111/anti.12360. This article may be used for non-commercial purposes in accordance with Wiley Terms and Conditions for Self-Archiving.

http://eprints.gla.ac.uk/149947/

Deposited on: 8 November 2017

Enlighten - Research publications by members of the University of Glasgow http://eprints.gla.ac.uk 


\section{Beyond the Right to the City: Territorial Autogestion and the Take over the City Movement in 1970s Italy}

The road leading to freedom is full of obstacles and accidents, especially the political emancipations that are mistaken for true liberations (Lefebvre 1968:134).

Henri Lefebvre's celebrated thesis in the Right to the City (1996) has long held promise as "both working slogan and political ideal" for a new urban politics (Harvey 2008:40), establishing the urban problematic in political consciousness, just as Lefebvre intended. Yet its mobilisation routinely falls behind Lefebvre's radical critique of liberal democratic rights elsewhere, as in The Sociology of Marx (1968), which was written contemporaneously and from which the epigraph above is derived. The right to the city (RttC) term has tended to signify urban rebellion rather than proving its practical content and now risks becoming a cliché. Here, I undertake a critical examination of the concept before exploring by contrast the 'Take over the City' (TotC) autonomous movements of 1970s Italy (Lotta Continua 1973). These largely unheralded forms of ‘territorial community activism' (Bologna 2007), I argue, surpassed the RttC idea through praxis. They produced immanent forms of urban struggle that can be productively compared with Lefebvre's conception of 'territorial autogestion' as an urgent utopia that might contest the existing order "from the world of the commodity and the power of money to the power of the State" (Lefebvre 2009:148).

Rights, paradigmatically speaking, are symbolic of social parity, provide an important bulwark against attacks on living conditions, and a progressive rhetorical 'ideal' against which the behaviour of powerful actors can be measured and challenged (Williams 1991; Brown 1995; Mitchell 2003). These are arguably especially important concerns for subaltern subjects (Williams 1991; Williams Jr., 1987). However, such qualifications do not vitiate the limits of rights discourse within the liberal democratic order, whose "unifying assumption" is possessive individualism and private property rights (Macpherson 1962:v). Nor do they necessarily inform us of how rights operate in practice and what political culture they generate, sustain or deny. Indeed, claims to rights often exacerbate the reproduction of the uneven power relations they aim to overcome (Brown 1995; Hartman 1997; Porter 2014) and tend to cauterise the hard-fought political experiences that gained rights in the first place (Tushnet 1984; Coulthard 2014; Merrifield 2013). 
Unpacking these contentions, I frame here a three-fold critique of the RttC. Firstly, I question the reformist mobilisation of RttC discourse. Secondly, I contrast this diminished mobilisation with the radical TotC movements in 1970s Italy, advancing a reading of 'spatial composition' in Italian autonomy. Thirdly, I argue that Lefebvre's lesser-known concept of 'territorial autogestion', brought into dialogue here with the TotC movements, may help radicalise, or supersede, RttC claims. Re-appraising extant primary and secondary literature, including manifestos, statements, interviews, analysis and reports from and within the autonomous movement in Italy, I affirm a distinctively spatialised autonomous politics. I stress the necessity of constructing a social force that places the direct appropriation of social resources on the immediate horizon without waiting for permission from a state that might, or might not, dispense them as a right. Whether the goal is dismantling the capital-state nexus or parliamentary reform, I argue that collective social force and the threat it carries to existing structures of domination must be the sine qua non of transformative politics.

\section{The Right to the City and its Limits}

...the legal-ideological matrix of freedom-equality is not a mere 'mask' concealing exploitation-domination, but the very form in which the latter is exercised (Zizek 2009:125).

Marxian thought is fundamentally anti-state (Lefebvre 1968:126).

Lefebvre's (1996:158) "cry and demand" for the RttC has become a popular clarion call in radical urban geography (Mitchell 2003; Harvey 2008; Mayer 2009; Attoh 2011; Merrifield 2011, 2013), yet it increasingly operates as an "empty signifier" due to the abstraction of its terms (Harvey 2012:xv-xvi). Fuzzy definitions of rights raise basic questions over how rights are defined, whose rights are being identified and for whose benefit; and the incorporation of rights within liberal democracies necessarily has costs and trade-offs that are rarely taken into account (Attoh 2011; Porter 2014). Indeed, it is now a basic banality to observe that the RttC slogan has long been recuperated by everyone from small-scale NGO's, to national state agencies, to the World Bank, for purposes that directly contradict Lefebvre's aims (Mayer 2009; Souza 2010; Merrifield 2011). In this way, Lefebvre's otherwise radical approach suffers from social force Lefebvre posits as a "necessary (but not sufficient)" condition for a new urban life (Lefebvre 1996:157) is routinely eclipsed by 
reformist institutional measures and pseudo-participatory mechanisms of state-control (Souza 2010).

This attenuation of the RttC slogan disavows Lefebvre's broader philosophical and political framework. His avowedly Marxian critique of rights, like that of the TotC movements, involves a rigorous critique of political economy and the state. In Critique of Hegel's Philosophy of Right (1843), Marx argued, contra Hegel, that the critique of juridicial and political philosophy should be the critical analysis of modern statecraft set over and above civil society, just as the critique of religion should be a criticism of heaven being set over and above earth. In The Sociology of Marx (1968:127), Lefebvre reads this to mean that mankind will realise his [sic] potentiality "not at the level of the state, in the state, or in what depends on the state, but by freeing himself from the state". In On the Jewish Question (1844), Marx observes how the French 'Declaration of the Rights of Man and of the Citizen' of 1973 was only a declaration of rights for 'man' in the singular: "an isolated monad, withdrawn into himself". In practice one's right to liberty, he argues, is one's "right to private property"; a right of self-interest and egoistic individualism reflecting an abstracted view of citizens under the universal equivalence of exchange, masking real differences in wealth, privilege, power, occupation, kinship, etc. Lefebvre similarly contends that the rights of the citizen "are abstract and fictitious. All they grant the individual is an imaginary sovereignty within an unreal universality" (Lefebvre 1968:130). The allegedly egalitarian doctrine of rights, he continues, in reality has "the function of organizing scarcity, of distributing with seeming equality the products of a basically unequal society" (Lefebvre 1968:179).

In Marxist Thought and the City (2016), Lefebvre asserts that the three volumes of Capital are neither a treatise on political economy, nor a critique of bourgeois political economy, nor the basis of a socialist political economy, but a critique of "all political economy" (Lefebvre 2016:59). Likewise, the Marxian critique of the state "is not limited to the Hegelian state, the bourgeois state, but extends to democracy, to the so-called democratic and socialist state - of every state (as a source of power)" (Lefebvre 2016:59). Revolutionary praxis means going "beyond democracy and beyond the democratic state, to build a society without state power" (Lefebvre 1968:138). Thus, Lefebvre's use of the RttC term, though far from liberal, is arguably deeply misleading given his wider political and philosophical outlook. By contrast, the 'Take over the City' slogan (see Lotta Continua 1973) is much less ambivalent in relation to the position and praxis of those who proposed it. 
Yet, some scholars in the US have defended the legitimacy of rights claims, characterising rights critique by critical theorists as a problematic white privilege denied to racialised and other marginalised subjects (Williams 1991; Williams Jr., 1987). For Black people in the US, Williams (1991) stresses, rights are desired precisely because they have historically been denied in a racist and privatised socio-economic culture where the bodies and space of Black people are routinely invaded with disregard. The possibility of attaining the sanctity of one's own individual boundaries through rights, she argues, provides a profound sense of hope and meaning for those who do not already have access to rights. Moreover, Williams Jr. (1987:120) adds that the critique of rights by critical legal scholars is inattentive to the reality of the struggles and needs of Black and other racially marginalised people in the US, functioning as a "a counter crusade to the hard campaigns and long marches of minority people in this country".

Such arguments are morally and practically compelling. Yet many Black scholars, materialist feminists, indigenous scholars and critical legal rights activists insist that a critique of rights is necessary for a radical transformation of the very conditions that reproduce the issues that rights claims aim to mitigate. Hartman (1997) challenges Williams' defence of rights by arguing that the stipulation of abstract formal equality via the state in fact produces white entitlement and Black subjugation. The fragile "as if equal" discourses of liberal rights discourse, she contends, disavow the histories of racial domination and violence that have underpinned the rhetoric of democratic equality (Hartman 1997:116). Given the structural relation between property, rights and slavery, she questions whether it is possible "to unleash freedom from the history of property that secured it" (Hartman 1997:119). Discussing the opposing conceptions of rights pursued by Marx (1844) and Williams (1991), Brown (1995) similarly asserts that rights claims downplay the centrality of property to liberal rights (see Marx 1844; Macpherson 1964). If the primary underlying assumption of rights in capitalist orders is the right to private property and its disposal, she contends, then real emancipation from private property "requires the abolition of private property, not the abolition of distinctions based on private property" (Brown 1995:132). Mitchell (2003:19-20) likewise contends that the RttC must be asserted "not within, but against the rights of property", noting that property rights are necessarily exclusive, and citing Lefebvre's call for the right to housing (and its use value) as distinct from the right to property (and its exchange value). Meanwhile, Porter (2014), discussing Aboriginal land rights, argues that claiming recognition 
on the basis of Anglicised property law tends to co-opt struggle into the language of individual possessory rights, diluting broader challenges to private property per se (see also Coulthard 2014).

Ultimately, for Foucault (1980:94), "the essential function of the discourse and techniques of right has been to efface the domination intrinsic to power" (see also Tushnet 1984; Fudge and Glasbeek 1992; Brown 1995; Žižek 2009). Due weight, Foucault argues, must thus be given to the fact of sovereign domination in rights discourse and its power to constitute subjects via biopolitical and governmental dispositifs. As Agamben (1998:134) instructively contends, the figure of the refugee "radically calls into question the fundamental categories of the nationstate, from the birth-nation to the man-citizen link" and thus the originary fiction of liberal modern sovereignty (see also Nevins 2017). Such wide reference to rights critique from Black, indigenous and migrant positions, aims to show that the notion of citizenship, from which active rights are derived, is neither universal nor absolute, and also seeks to function as a form of "creative destruction" (Tushnet 1984:1363) clearing space for more radical approaches based on building and maintaining collective power from below. Rights undoubtedly provide at least some limited bulwark against attacks on current living conditions, and it would be foolish to dispense with this tool. But the argument here, exemplified in the 'Take over the City' slogan, is that social force is a vital prerequisite for even limited rights gains and must therefore be a central strategic concern.

\section{The Right to Appropriation: 'Social Force' over Rights Discourse?}

The right to the oeuvre, to participation and appropriation (clearly distinct from the right to property), are implied in the right to the city (Lefebvre 1996:173-174).

Lefebvre's RttC involves two principal rights for urban inhabitants: the right to participate in all decisions in the management and production of urban space, and the right to appropriate (Purcell 2002; Hodkinson 2012; Vasudevan 2015). Regarding the latter, Mitchell (2003:6) stresses that rights are only ever won through concerted struggle: there is a need, he says, to not only produce urban space "but to actively take it, if a claim of right is to be made". Yet such claims, he continues, are always limited, contested and only proven in practice - they are never guaranteed in the abstract. Indeed, in the Right to the City, Lefebvre (1996:157) describes how "concrete rights", established as a consequence of collective political struggle, 
have typically become toothless "abstract rights", following top-down "prescriptions" and "enactments" via parliamentary democratic and legalistic forms. Against such pseudo-rights, he claims, only "social force" can shatter the limits of such forms (Lefebvre 1996:156). As Merrifield contends, rights are ultimately about collective social power; they are not about 'recognition' by a higher arbiter, they must be taken:

Let's forget about asking for our rights, for the rights of man, the right to the city, human rights. A politics of the encounter utters no rights, voices no claims. It doesn't even speak: rather, it just does, just acts, affirms, takes, takes back. It doesn't ask, doesn't plead for anything abstract (Merrifield 2011:479).

A bill of rights, he asserts, is the end, not the means, of enforcing democratic rights. Indeed, while the achievement of rights is rarely the goal of an extra-parliamentary politics of direct action, it routinely surpasses reformist ideology in that objective, which, as Lefebvre (2009:140) once noted, typically results in a "reformism without reforms". As Coulthard (2014:167) observes, successful reformist negotiations over rights have historically "piggybacked" on the assertiveness of direct action movements, when the threat to governance, property and profit carried by direct action has forced governments to concede rights (Mitchell 2003). Crucially, such social force goes beyond immediate gains to build collective power, confidence and autonomy in the long run, while destabilising state domination and short-circuiting a problematic politics of recognition. As Federici (1975:7), a key figure within autonomous feminism, adroitly contends, it is one thing to organise and appropriate communally and then demand that the state pay for it, and it is another to ask the state to organise communal production: "In one case we regain some control over our lives, in the other we extend the State's control over us". Against such seductive assimilation, the Italian autonomous movements of the 1960s and 1970s recognised that social force (in all its variegated dimensions) was crucial for the expansion of autonomy, political recomposition and a re-appropriation of the wealth that their labour had produced without reward. To these movements I now turn.

\section{Laboratory Italy: Autonomy and Spatial Composition}

I take Italian revolutionary politics as a model [...] because it has constituted a kind of laboratory for experimentation in new forms of political thinking that help us conceive a revolutionary politics in our own times (Hardt, 1996:1) 
As Hardt observes, the practices of political autonomy from the 1960s to the late 1970s in 'Laboratory Italy' constitute an anomaly with respect to comparable Western countries in terms of size, intensity, creativity and duration (see Lumley 1990; Wright 2002; Lotringer and Marazzi 2007). His comparison with 'May 68' in France is instructive: “whereas 1968 lasted only a few months in France, in Italy, it extended over ten years, right up until the end of the 1970s" (Hardt 1996:2). Centering on the auto-plants of Northern Italy and reaching a peak in the 'Hot Autumn' of 1969, the movement operated under the banner of Operaismo ('workerism'). Italian 'workerism' should not be confused with an over-emphasis on industrial workers to the exclusion of all other social subjects. Instead, it designates the primacy placed on workers' collective experience, autonomy and agency against their mediated representation by Left parties, unions and bosses (Wright 2002). Notably, Operaismo was premised on the 'refusal of work' rather than its reification (Tronti:1972; Wright 2002) and there are strong parallels between Lefebvre's $(2009,2016)$ critique of political economy and 'state productivism' and the autonomous concept of the 'planner state' (Cleaver 1979; Negri 2005; Wright 2002). Central to Operaismo and its derivations, was Tronti's seminal 'Copernican revolution', which inverted standard understandings of capitalist development and the class relation by arguing that labour and the pressure of workers' struggles (aka 'social force') is the main catalyst for capitalist development:

We too have worked with a concept that puts capitalist development first, and workers second. This is a mistake. And now we have to turn the problem on its head, reverse the polarity, and start again from the beginning: and the beginning is the class struggle of the working class (Tronti:1964).

This emphasis is crucial but should not be applied a-historically or ontologically. As Böhm et al (2010:28) observe, autonomy is not a "good outside" that allows an escape into pure selfdetermination, but an antagonistic political position that is immanent to existing relations. As Wright (2002) observes, the question of political decomposition is every bit as real as that of recomposition. Class composition was probably the most important concept to be developed within Operaismo, taking the place of the concept of hegemony for its practitioners, aiming to grasp in praxis the 'social force' that Lefebvre thought necessary for forging urban revolt. Class composition can be understood as a nuanced dialectical relation between 'technical' and 'political' composition. 'Technical composition' refers to organised capitalist production, including the division of labour, technological deployment, social planning, supervision and discipline. 'Political composition' refers to the degree to which workers make collective 
political subjectivity and organisation a basis for counter-power (Cleaver 1979; Wright 2002; Negri 2005). The category of the 'mass worker' inaugurated class composition as method and practice. It was not a ready-made category simply designating a mass of workers in industry, but instead a strategic neologism designed to conceptualise and augment the political recomposition of the labour force within mass industry in 1960s Italy.

With the mass worker category, the workers' movement organised against the specialised division of labour in the factories, demanding the abolition of wage differences, and rejecting hierarchical job classifications, piecework and productivity-linked bonuses (Bologna 1991; Negri 1987). The category helped recompose racial and cultural divisions between Northern industrial workers and migrant labourers from the South, generating new forms of unity and rebellion where internal divisions had previously been fostered by factory management and the unions (Negri 1987; Wright 2002). The pugnacious tactics of the mass worker in the 'Hot Autumn' of 1969 helped force 23.4\% wage increases between 1969 and 1970 alone (Dowson 1973). By the early 1970s, however, the mass worker was gradually being displaced as the chief protagonist in the struggle against capital via industrial restructuring. Just as the mass worker had deposed the 'professional skilled worker' in the early decades of the twentieth century, Negri (1987) argued, so the 'socialised worker' came to supplant the mass worker by the early 1970s. The speculative concept of the 'socialised worker', derived from the 'Fragment on Machines' in Marx's Grundrisse (1993), refers to the diffusion of productivity across the entire production and circulation process (the 'social factory') and with it the potential generalisation of class struggle (Tronti 1962; Negri 1987).

The socialised worker thesis and its derivations (the immaterial, cognitive or affective labourer) have since come in for strong critique, for proceeding non-empirically and anticipating results still to be proven (Wright 2002); and for overlooking the gendered caring labour that reproduces the male worker for production (Federici 2004). My intention here, however, is not to develop debates around this category, but rather to excavate the urban politics of the TotC movements that lie, typically under-examined, between the mass worker and the socialised worker. In doing so, I develop the notion of 'spatial composition', by which I mean a study of the relation between the technical and political composition of capital, focusing on the tendential shift from industrialisation to urbanisation that Lefebvre (1991, 2003) so presciently foresaw from the late 1960s onwards. This shift of focus allows us to perceive how central autonomous categories and practices from the 1960s (the inversion 
of class perspectives, the refusal of work, the social factory, class composition) were retheorised in the 1970s to generate new grounds and new subjects of struggle.

\section{Spatial Composition: New Grounds and New Subjects of Struggle}

A considerable part of the political behaviour of the young proletariat during the recent struggles should be understood starting from city planning as a space of intervention in class dynamics (Bologna 2007:43).

The period 1973-74 is considered the moment when the mass worker was displaced as the primary social subject in the struggle against Italian capital (Castellano et al. 1996). Chierki and Wieviorka (2007) describe the institutional context for this transition. In a context of industrial decomposition and economic crisis, the Christian Democrats (DC) developed the 'Carli Plan' in 1973 with the tacit support of the Italian Communist Party (PCI) as part of the 'Historic Compromise', a conservative alliance between the DC and the PCI that began in the same year. This austerity plan, redolent of the contemporary juncture, restructured and diversified industry in an attempt to decompose the militant mass worker, reduce public expenditure drastically, and shift the burden of crisis reform onto the working class through massive price hikes in the sphere of consumption. Crucially, this led to a recomposition of political struggle: the new social subject was now concerned with "conquering and managing its own "spaces" and "the concrete and articulated exercise of power on the social terrain" (Castellano et al. 1996:231).

In The Tribe of Moles, Bologna's (2007) description of the specific relation between monetary crisis, the planner state and the property market, conforms to the thesis of 'capital switching' from the 'primary' circuit (industry and manufacturing) to the 'secondary' circuit (land, property, real estate and the built environment) that Lefebvre pioneered (Lefebvre 2003; see also Harvey 1985). The property interest, Bologna observed, was dependent on the 'party system', with the PCI and DC controlling vast tracts of land. Yet, construction companies had the overall power to direct the dynamics of development. Between these factors, land bargaining provided the means to diversify from the 'productive' economy into property speculation with the construction cycle functioning "as a pump to drain away income from workers and redistribute it to the middle classes on the one hand, and to the 'construction interest' on the other" (Bologna 2007:42). Bologna presciently described how real estate investment trusts and pension funds in suburban property and land became a refuge for capital surplus. With such surplus dumping (see Harvey 2008, 2012), the value of 
suburban areas rose significantly, making it more profitable for capital to develop suburban housing. This moved certain social strata with higher incomes away from city centres, instigating an urban fiscal crisis as inner cities were deprived of rates and taxes. Preceding contemporary discussions around liquidity in the built environment via financial instruments such as mortgage-backed securities, Bologna observed how specific financial structures were created that subjected the "petrification of capital" in city centres zones to:

...a series of special speculative institutions, invented through the crisis, which have increased the rhythm of transfer of property deeds and have given a considerable impulse to the velocity of circulation of money, without it passing through a process of production (Bologna 2007:42).

Simultaneously, as industry developed in the 1960s, the northern industrial cities went through massive population growth receiving an enormous influx of migrant workers from Southern Italy. The main State Housing agency, GESCAL, did little to alleviate this issue. By 1971, many workers were sleeping up to eight to a room, shanty towns spread in the large industrial cities, and rents consumed up to $40 \%$ of wages (Dowson 1973). Workers' demands on wages and conditions had undermined the massive profits of the boom years in industry. Capital thus fled abroad or into lucrative internal property markets, leaving behind surplus workers in atrocious housing conditions. As Bologna (2007:43) observed, charting the political as well as the technical side of spatial recomposition, the impact of such urbanisation led groups to organise around "a reconquest of the city centres", reacting to unplanned and uncontrolled city planning as an immanent, dialectical terrain of struggle and generating new waves of "territorial community activism". The decomposition of the 'mass worker' was thus reconfigured as "the key point of departure for organisation" in the wider sphere of social reproduction (Bologna 2007:47).

For Bologna (2007:49), the emergence of autonomist feminism was a "decisive event" in this movement of political recomposition around the reproductive sphere. Issues of gender had previously been subordinated to that of class, with the needs of the women's movement postponed until after the conquest of State power (Bono and Kemp 1991; Cuninghame 2008). This situation generated a fundamental feminist critique of the political forms and practices of both the 'New' and 'Old' Left. In the early 1970s, a new conception of autonomy, taking greater account of feminist agency, emerged to challenge reified divisions between the public and private sphere and between the formal workplace and domestic work. Mass mobilisation 
campaigns became a distinctive characteristic of Italian feminism, with widespread struggles taking place over the control and cost of general social reproductive needs (health, housing, transport, leisure and consumption) and conservative abortion and divorce laws (Bono and Kemp, 1991; Cantarow 1976; Bracke 2013).

The reworking of Tronti's 'social factory' thesis was crucial for autonomist feminism and the TotC movements more generally. The term designates the real subsumption of society under capitalist relations; the erosion of distinctions between the workplace and society; and the transformation of the entirety of social relations, potentially, into direct relations of production "invading the whole network of social relations" (Tronti, 1962). In practice, the potential of this category for political recomposition rarely delivered on its promises within Operaismo (Wright 2002). But as Cleaver (1979:59) observes, the cogency of the thesis was immediately apparent to the autonomist feminist movement, who "grasped not only the theoretical concept of the social factory but also the key role of the struggle of non-factory workers - most of whom were women". With the influential publication of The Power of Women and the Subversion of the Community (Dalla Costa and James 1972), an understanding emerged that the 'hidden abode' of unpaid reproductive work provided the basis on which the exploitation of waged workers was built, revealing "the secret of its productivity" (Federici 2004:8). This analysis of the sexual division of labour offered a "material foundation" for the domestic labour debate and the Wages for Housework (WfH) movement, launched in Padua in 1972 (James 1975; Bracke 2013). Lotta Femminista (Feminist Struggle), the feminist section of Lotta Continua (Continual Struggle), co-ordinated the WfH campaign, reworking the 'refusal of work' thesis to give the campaign an explosive, politicised and radical anti-work character, epitomised in the 'Wages against Housework' slogan (Federici 1975, my italics).

Such interventions usurped received Marxist categories, but stressed material struggle over feminist consciousness-raising, and a feminist critique of political economy over 'equal opportunities' in the existing labour market (Federici 1984). Working with, through and against both Marxian categories and the women's liberation movement, autonomist feminists criticised Marx's inability to conceive of value-producing work outside the formal workplace; his consequent blindness to the significance of women's unpaid reproductive work in the process of capitalist accumulation; and his oversight regarding the function of the wage in the creation of divisions within the working class, especially between men and women (Federici 2004). With this understanding, "a whole set of assumptions about trade unionism were [...] 
called into question" (Lumley 1990:325). When the question of housework was raised, the trade unions were forced to acknowledge that they dealt: "(a) only with the factory; (b) only with a measured and 'paid' work day; (c) only with that side of wages which is given to us and not with the side of wages which is taken back, that is inflation" (Dalla Costa and James 1972:34). With community and the home envisaged as part of the wider social factory, however, the entire terrain of social reproduction was opened up for legitimate political contestation:

Every place of struggle outside the home, precisely because every sphere of capitalist organization presupposes the home, offers a chance for attack by women; factory meetings, neighbourhood meetings, student assemblies, each of them are legitimate places for women's struggle (1972:38).

Social reproduction struggles, theorised and led by autonomous women, became a vital nexus of a broader class recomposition in the 1970s, cutting across a wide movement of workers, students, women, the unemployed and youth (Bologna 2007; Cuninghame 2015). Yet, it is important to stress that the feminist focus on the body and social reproduction was greeted with animosity by many men in both the 'New' and 'Old' Left, with social reproductive struggles routinely viewed as secondary to those in the sphere of production and subordinate to class struggle rather than a necessary extension of it (James 1975; Bono and Kemp 1991; Bracke 2013). Such problems should not be glossed over. However, by stressing the paradigm of social reproduction as an immanent material concern for everyone (though clearly in distinctively gendered forms), political praxis in this area in 1970s Italy offers vast potential for re-examination today. Before providing a necessarily partial description of how autonomous feminist praxis was productively imbricated in the urban TotC movements, I briefly explore Lefebvre's notion of 'territorial autogestion' as a means of potentially radicalising or superseding RttC claims; and of grasping the ongoing relevance of the Italian TotC movements.

\section{Beyond Rights, Towards Territorial Autogestion}

Only through autogestion can the members of a free association take control of their own life, in such a way that it becomes their work [oeuvre]. This is called appropriation, dis-alienation (Lefebvre 1966:150). 
Lefebvre endorsed autogestion (self-management) as a form of militant democracy long suppressed by State and Party ideology (Brenner and Elden 2009). His notion of autogestion can be seen as the practical means of achieving the RttC, in its most radical sense, and as a material elaboration of praxis within Lefebvre's political-philosophical matrix. For Lefebvre, autogestion carried within it the possibility of radicalisation and generalisation, crystallising the contradictions of the state form: "In essence, autogestion calls the State into question as a constraining force erected above society as a whole, capturing and demanding the rationality that is inherent to social relations (to social practice)" (Lefebvre 2009:147). Thus, rather than Brenner's (2001) unlikely depiction of Lefebvre as a Poulantzas-like theorist of the state, Charnock's (2010:1279) description of Lefebvre as an 'Open Marxist', harnessing dialectical thought "to critique the very categories that constitute the capitalist system" is more apposite. As Lefebvre (1968:164-165) notes, Marx was not Machiavellian. His strategy was based on the strengthening of the proletarian movement and the supersession of formal politics and the state. In Lefebvre's conception, autogestion was a potential means for achieving these objectives.

Like all social relations, however, autogestion can easily degenerate into ossified ideology. Thus, Lefebvre criticised Yugoslavian planned autogestion, the most institutionalised example of autogestion in the late $20^{\text {th }}$ century, as a bureaucratic "model" from above that imagined it could maintain social democratic state power without contradiction or disharmony (Lefebvre 2009:135; see also Zukin 1975; Ronneberger 2009). In line with his critique of political economy, Lefebvre argued that autogestion in itself does not challenge the value form per se, either in theory or practice, thus risking the reification of what Adorno (2001:201) termed 'pseudo-activity': “the attempt to preserve enclaves of immediacy in the midst of a thoroughly mediated and obdurate society". As Dauve and Martin (1997) argued in the influential post-Situationist tract, The Eclipse and Re-Emergence of the Communist Movement, in a totality of social relations defined largely by private property, abstract labour and the law of value, self-management risks making us merely the masters of our own exploitation. Yet, while conscious of this problem, Lefebvre maintained that processes of autogestion could help push the contradictions between use-value and exchange-value to their limit, restoring primacy to use value, and thus generating an opening towards the possible that might lead "beyond political democracy" (Lefebvre 2009:150). He saw autogestion as a "viable utopia" within the constraints of the present, troubling abstract distinctions between reform and revolution (Ronneberger 2009:104). 
In a distinctive move in autogestion theory, Lefebvre, the seminal theorist of the transition from industry to urbanisation, added the prefix 'territorial' to autogestion, transposing the problematic "more and more from enterprises towards the organization of space" (Lefebvre 2009:160). While autogestion has tended to privilege productive workers, classically understood as those who produce surplus value directly, Lefebvre's conception of production encompassed "in the fullest sense of the term, reproduction" (cited in Ronneberger 2009:91). Territorial autogestion, he contended, includes the "low to high" of social space at all levels, transgressing traditional separations between public and private, work and non-work, production and reproduction (Lefebvre 2009:193) and evoking the potential for "the possession and collective management of space by a permanent intervention of 'interested parties"” (Lefebvre 2009:195).

In this sense, territorial autogestion mirrors the concept of the social factory as practically grasped by autonomous feminists in the wider arena of social reproduction. Unfortunately, Lefebvre provided little evidence of how territorial autogestion has been worked out in practice. The rediscovery of a previously unpublished proposal by Lefebvre and the French architects, Serge Renaudi and Pierre Guilband, for the International Competition for the New Belgrade Urban Structure Improvement in 1986, has autogestion at its core (Bitter and Weber 2009), but the tradition of self-management in former Yugoslavia that made the proposal attractive for Lefebvre, despite his reservations about the Yugoslavian variant, was in substantial decline by the 1970s (Ronneberger 2009). Yet, as we will soon see, many parallel concerns were carried forward en masse by the Italian autonomous movement in 1970s Italy. These struggles perceived the problem of self-management, as Lefebvre did, as a way of building social force, and exploring the contradictions between use-value and exchange-value (Wright 2002:114-115). As such, they intimate in historical praxis how territorial autogestion might be conceived in the present conjuncture.

\section{Take over the City: Territorial Autogestion in Practice}

All these struggles have relied on direct action: 'Legal' channels for registering protest or demanding reforms are seen for what they are: delaying tactics used by the ruling class to divide people and buy off their leaders. Appeals to politicians, petitions to Parliament, and the like have been rejected as irrelevant if people are prepared to fight to take now the things that they need (Dowson in Lotta Continua, 1973:81) 
As Chierki and Wieviorka (2007) argue, a consideration of social struggles in Western Europe since 1968 must learn from the mass neighbourhood struggles tied to consumption in 1970s Italy. This activity concretised Lefebvre's notion of territorial autogestion, inaugurating a collective set of appropriative practices across the entire socio-spatial sphere as a response to inflation and property speculation. Key tactics were typically extraparliamentary but often involved radical factions in the unions: rent strikes, squatting, occupations, and 'autoreduction' (or self-reduction), which had developed in the factories as a means to collectively reduce the hours of work and the rate of productivity, and were later applied to reduce, through direct action struggle, prices in housing, transport, public services, utilities, leisure and cultural consumption (Ramirez 1992; Cherki and Wieviorka 2007). In necessarily abbreviated form, I provide examples from the TotC movements through three crucial texts (Lotta Continua 1973; Cherki and Wieviorka 2007; Ramirez 1992), focusing on spatial struggles and autoreduction and stressing the expanded political recomposition that emerged in and through these struggles.

\section{Spatial Struggles}

Lotta Continua, an extra-parliamentary group that emerged from the worker-student movements of the late 1960s and Potere Operia, were central to the urban struggles that emerged in the early 1970s. Drawing from these tendencies, they simultaneously helped socialise workerism and workerise the student movement by constructing a network of grassroots communities around the entire country (Tarrow 1989). As with Operaismo, traditional distinctions between theory and practice in the movement were dissolved: "Lotta Continua [the group's journal] not only told people where the action was, it was part of that action" (Tarrow 1989:271). The political theory of Italian autonomy was measured within "the new composition of the class... and not in some set of statutes" (Bologna 2007:58). 'Take

over the City' became a central, and successful, mobilisation theme from 1970 (Tarrow 1989), and Take over the City - Community Struggles in Italy (1973), a report collectively written by movement activists in Lotta Continua, provides a vivid summary of urban contestation in this period. Mass urban struggles were geared against inflation beyond the factory; against the control of social services by large private firms (e.g. hospitals, schools, public housing, etc.); and against "the tyranny of rent" (Lotta Continua 1973:80). Rent strikes and the occupation or squatting of empty homes were seen as "part of the total working-class struggle", linked to factory struggles and other aspects of housing oppression such as "people facing eviction, squatters and homeless families" (Lotta Continua 1973:90). 
Nascent struggles over peripheral municipal housing in North-West Milan detonated questions around social reproduction, calling the state into question as an arbiter of social services, as in Lefebvre's notion of territorial autogestion. In 1968, in Quarto Oggiaro, 30,000 families in municipal housing with endemic existing rent arrears were faced with $30 \%$ rent increases (Lotta Continua 1973). Forcible evictions led to organised collective resistance, with 700 families on total rent strike by June 1968. 500 police officers were required to evict just one family in April 1970. On May Day 1970, around 2,000 people broke decisively with party and union tradition, demonstrating on the streets autonomously. An independent Tenants' Union was created, one of the first of its kind, demanding that rent should be no more than $10 \%$ of wages; and, following a number of isolated squats in Quarto Oggiaro and nearby Gallaratese, mass occupations began to emerge. An elderly local female tenant interviewed by Lotta Continua had a message for local women not yet involved:

We're using a new type of weapon to fight against the rising cost of living, against the bosses's exploitation of us in our homes. It's something really effective - a rent strike...Rather than give your money to the bosses, keep it for yourself. Give it to the children. Give it to the workers who are struggling in the factories and who are exploited year in year out (Lotta Continua 1973:86).

In 1971, 25 families occupied an empty block of flats in Via Mac Mahon. 2,000 police arrived, attacking the building with tear gas. Around a third of the families were arrested. The remainder joined a large crowd outside which in turn was tear-gassed. Refusing to be rehoused in a 'Homeless Families' centre, they occupied the Quarto Oggiaro Social Centre, eventually forcing the local Council to set free the prisoners and re-house all the families involved. In the same year in Milan, a whole neighbourhood was involved in a mass occupation of empty housing at Via Tibaldi, initially involving 70 southern immigrant families who had been promised re-housing without result. The people involved "occupied everything" in the district over the next six days: "houses, the streets, the town hall, police wagons, and the Architecture Faculty at the University" (Lotta Continua 1973:93). Led by an assembly of affected families, autonomous lines of struggle were clearly laid out: "It was homeless families, workers, and students against the bosses, the unions, the housing officials, and the police" (Lotta Continua 1973:93).

Fearing that this unrest, developed through large-scale demonstrations, would become "the symbol of Milan's working class" (Lotta Continua 1973:97), the Local Council were forced 
to meet all demands, allocating 200 apartments to the families involved, and 140 to others in a similar situation. Here, social force guaranteed social rights but it was understood that such gains could only ever be temporary and the struggle from below must be continually reenacted (see Lefebvre 2009; Mitchell 2003). Grass-roots assemblies were maintained to organise against future increases in rents, fares and prices. In the same year, similar actions arose in San Basilio, Rome, where 100 families went on rent strike and where hundreds of families in peripheral overcrowded 'shanty-towns' occupied luxury apartments left empty by speculators in the city centre. Even in the South of Italy, in places like Taranto, Palermo and Naples, where organisation was more difficult, widespread housing occupations challenged a chronic lack of services and the political cronyism that saw housing allocated on the basis of party affiliation.

Lotta Continua stressed the primary role of women in such housing struggles. Women led anti-eviction squads and the guarding of buildings from rent collectors and the police. They made links with nearby factories and directly organised rent strikes - "block by block, staircase by staircase" - by way of regular meetings, newsletters, posters and demonstrations (Lotta Continua 1973:80). As Ramirez (1992) observes, capital and state were intent on exploiting the sexual division of labour, by targeting the sphere of consumption. Yet, this strategy only revealed with clarity "the importance of the home as a unit of production, and housewives as protagonists of the struggle against capitalist planning in this sphere" (1992:192). As one evicted woman worker who occupied an empty flat in Quarto Oggiaro stressed: "A home is a right, and in the name of that right I have taken one!" (Lotta Continua 1973:87). A male worker from Quarto Oggiaro added: "We're the ones who build the houses. We're the ones who work in the factories... Houses are ours because we build and need them, and for that reason we're going to have them!" (Lotta Continua 1973:88). This unified and combative struggle around housing was a pre-condition and model for the extension of appropriative struggles across Italy in the areas of housing, transportation, utilities, and other sectors. Autoreduction was central to these tendencies.

\section{Autoreduction}

Cherki and Wieviorka (2007) observe how autoreduction in Turin's housing sector broke with the traditions of the Left in the 1970s: "The homeless take over empty houses. Public housing tenants autoreduce rents or resist eviction. These struggles are illegal, massive and often violent" (2007:73). Between 1969 and 1975, 20,000 habitations were squatted and a 
series of rent autoreduction campaigns emerged with the goal of limiting rents to $10 \%$ of salaries. In the Magliana district of Rome alone, 2,000 families autoreduced monthly payments by 50\% between 1973 and 1975 (Ramirez 1992). Important parallel campaigns emerged in the transport sector, challenging increased bus fares (between 20\% and 50\%) around Turin, initially by blockading buses at key hubs. An autoreduction strategy augmented the campaign, building capacity and unity. Union delegates gathered subscriptions and provided receipts at the level of the old fares. Some companies curtailed certain lines in retaliation but workers' demonstrations and pressure by workers from local factories forced the regional authorities to intercede. The lines were opened again, and the old rates were reintroduced in a rapid success for direct action that soon spread across Italy (Cherki and Wieviorka 2007).

Autoreduction also escalated to the electricity sector where its "politically explosive" character was revealed (Ramirez 1992:187). The sector was then monopolised by the state, with prices equalised across Italy. Thus the policy and competence of the austerity state under the Historic Compromise, was directly challenged nation-wide, creating enormous potential for generalised struggle. Autoreduction committees sprang up across Italy. Neighbourhood committees in Turin and Milan, facilitated by an informal federation of local groups and supported by the unions and workers' councils in the factories initially, collected electricity bills and issued substitute bills, often stamped by sympathetic unions, which were autoreduced by around 50\% and then paid (Ramirez 1992). Tens of thousands of electricity bills were thus reduced across Italy. Turin led the way with 140,000 alone. Here direct appropriation, backed up by collective social force, exceeded rights claims. By defining and fighting for their own interests as a class, "working people [...] take back everything that has been stolen from them, taking control of their own lives and taking over their cities" (Lotta Continua 1973:80). For Ramirez, mirroring the aims of gemneralised territorial autogestion, the struggles around transport and utilities were most potent in neighbourhoods where they were woven together with squatting and rent autoreduction. It was the neighbourhood assemblies who maintained the self-reduction movement once the unions incorporated autoreduction at the factory level. This mediation "from above", designed to prove the disciplinary legitimacy of the organised Left in the Historic Compromise, had the effect of breaking many, but not all, autonomous links between neighbourhood and factory (Ramirez 1992:191). However, the autoreduction movement was notably strongest in Turin, where the unions involved had a relatively 'open' position to the radical Left, and relative autonomy 
from the national leadership. This allowed strong links to be established between the local unions, left militants, and neighbourhood assemblies with the latter maintaining considerable autonomy (Chierki and Wieviorka 2007:75).

Such links show how productive relations can be developed between autonomous militants and radical factions within the institutional Left as long as autonomy at the base is maintained. But by the mid-1970s, however, a brutal reaction to the autonomist movements was being reinforced by the DC, PCI, and associated unions in the name of national unity and economic growth. In 1979, They sanctioned a state of emergency that exiled hundreds of militants and left up to 12,000 jailed, untried under authoritarian laws of exceptionality which paid little heed to any rights talk (Lotringer and Marazzi 2007). In the area of housing, a Fair Rent Act (1978) was introduced, but this sapped the energy from the movement as the focus shifted to implementation, incorporation and unionisation (the union SUNIA was heavily linked to the PCI). Recuperation also occurred through a shift from autonomous Comitati di Quartieres (autonomous neighbourhood committees) to Consigli di Quartieres (institutionalised community councils with heavy PCI representation) (Marcelloni 1979). The PCI shifted the emphasis from militant political initiatives to exerting pressure on existing governing institutions via legal rights and reforms, thus "reducing the level of struggle and redirecting protests into more reformist channels" (Marcelloni 1979:265), and reinforcing the legitimacy of state and capital.

Tarrow (1989) has critically discussed the institutionalisation of the extra-parliamentary movements in this period of political decomposition, stressing that the PCI were the main beneficiaries of their activity. Yet his political science account is somewhat bloodless and undialectical, underplaying how militant social forced pushed the PCI to the Left on the one hand, and how the Historic Compromise pushed the PCI to the right, and eventual oblivion, on the other. His account also entirely neglects the notion of class composition, thus disavowing autonomous Marxism's "signal contribution to the intellectual arsenal of Marxism” (Toscano 2010: 200; Wright 2002), while failing to advance any speculative theses on class recomposition under historical conditions of fragmentation and dis-homogeneity (see Bologna 1977) himself. More productively, we might affirm the TotC movements in a twofold way. Firstly, as an attempt to grasp the problem of urbanisation as a mass objective that only seems more resonant now. Secondly, as a practical affirmation of Lefebvre's notion of territorial autogestion: a fundamentally antistatist constitutive political process across the 
entire social factory that must be "continually enacted" if it is not to ossify and atrophy (Lefebvre 2009:135).

\section{Conclusion: Learning from Laboratory Italy}

The TotC movements in 1970s Italy, I contend, embodied the practice of territorial autogestion as outlined by Lefebvre, and also his injunction to appropriate the urban rather than waiting for rights to be granted. In this way, they surpassed in practice the RttC thesis, which has tended to remain on the symbolic plane rather than being central to urban struggle itself. The TotC movements suggest a potent example of territorial autogestion as a wideranging assault on capitalist relations across the productive and reproductive spheres: "overturning dominant spaces, placing appropriation over domination, demand over command, and use over exchange" (Lefebvre 2009:194). Their vital "pugnaciousness" (Chierki and Wieviorka 2007:73) calls into question reasoned rights claims that tend to reinscribe rather than detonate existing relations of asymmetrical sovereign power through contradictory and bounded forms of recognition. Yet a specifically spatial understanding of 'Laboratory Italy' has only been glimpsed and here I conclude by outlining four tentative 'lessons' for a politics of space that might be gleaned from the territorial community activism of the TotC movements.

Firstly, autonomy, as derived from Italian Operaismo, is not 'a good outside' but an immanent, collective political practice that aims to challenge the subsumption of socioeconomic relations within a determinate historical epoch (Böhm et al.:2010). This is crucial since citizens are now routinely subject to autonomy imposed from above, including scalar dumping via devolved governance, downloaded responsibility and externalised austerity (Böhm et al::2010; Peck 2012). In this context, an immanent grasp of the relation between technical composition ('capital's plans') and political composition (the extension of unified organisation as a basis for counter-power) is vital for short-circuiting the limits of autonomy, conceived reductively as an ontological and a-historical condition. The tendential shifts in spatial composition identified and challenged in 1970s Italy, including 'capital switching' into the urban environment and the development of the rentier economy, are now fully entrenched as Lefebvre presciently foresaw. A renewed spatial composition analysis in the present era may thus have significant traction for contemporary modes of political recomposition. 
Secondly, organising communally and forcing the state to pay for the satisfaction of social needs is quite different from asking the state to organise communal production (Federici 1975). In a period of political decomposition, with an attendant foreclosure of mandates for action, collective social force, and social threat, are a pre-requisite for political recomposition. Without such militant self-organisation, social movements remain passive and dependent on the state and capital (Lefebvre 1968; Mitchell 2003; Chierki and Wieviorka 2007). The TotC movements provide stellar models in this regard, suggesting potential outlines for political recomposition between workers, women, migrants, the low-waged and the unemployed, in line with Lefebvre's conception of generalised territorial autogestion across productive and reproductive spheres. The repressive response the movements faced indicates both the potent threat they carried and the violent face of the state. However, rather than revealing the limits of direct action, they instead provide instructive lessons on the limits of liberal rights discourse under the asymmetrical power relations associated with the democratic state.

Thirdly, as numerous commentators have stressed, wage gains in the workplace are routinely rendered meaningless through inflation at the level of consumption (Dalla Costa and James 1972; James 1975; Ramirez 1992). During a period of austerity, such as we face today, it is harder to enforce strikes, refuse regulated work pace, and struggle against increases in productivity. Conservative campaigns to retain jobs and defend salaries become more typical. The point here is not to undermine or undervalue the necessity of labour struggles, but defending the 'social wage' in times of austerity necessarily also requires "struggling in the area of consumption" (Cherki and Wieviorka 2007:74-78). The global rise in housing costs, and the associated consequences for workers' earnings, is only the most telling case in point. Grasping the immanent political potential in the spatial composition of capital, as Lefebvre and the TotC movements did in the late 1960s and early 1970s, is crucial to opening up a 'double-front' between productive and reproductive spheres.

Fourthly, the struggles of women in the area of social reproduction must be understood as a struggle for everyone who struggles against capitalism (Federici 1975). Caring labour and the costs of utilities, food, transport, housing, etc. fall on women more than men, situating women as central figures of subversion in the community. This understanding was vital for the new territorial struggles that developed across the social factory in 1970s Italy. As Dalla Costa and James (1972:34) observe, class struggles in both direct production and the arena of social reproduction have always been dependent on the formal/informal organisation of women. Against a false presentation of the unity of class interest predicated on a male wage 
labour force, James (1975) contends that "nothing unified and revolutionary will be formed until each section of the exploited will have made its own autonomous power felt". For James, such statements were meant to redefine not obviate class struggle. Deepening consideration of the arena of social reproduction as a general immanent concern offers a way of breaking down existing hierarchies, and building collective social force, without sacrificing difference to the alter of false unity.

In conclusion, I have argued that the largely unheralded TotC movements in 1970s Italy hold potentially vital lessons for contemporary urban politics. Learning from Laboratory Italy, and relatedly from Lefebvre's notion of territorial autogestion, involves understanding how an immanent politics of space might emerge from internal changes in the spatial composition of capital. Going beyond the dichotomies of a phenomenology of resistance and the deficit of praxis associated with 'capital-centric' studies, the TotC movements aimed to grasp the perpetually transforming relation between "subjective forms of political action and the shifting configurations of space" (Toscano 2010:198). In this way, they posited a generalised material politics of space that might hold clues to superseding the largely symbolic promise of the RttC slogan. As Lefebvre contends, the constitution of a collective insurgent 'social force', that grapples with a critique of political economy and the state-form, is a sine qua non for this possibility. For being set free by the master is not the same as setting oneself free.

\section{Bibliography}

Adorno T (1991) Resignation. In J M Bernstein (ed) The Culture Industry: Selected Essays on Mass Culture. London: Routledge: 198-204

Agamben G (1998) Homo Sacer: Sovereign Power and Bare Life. California: Stanford University Press

Agamben G (2005) State of Exception. Chicago: University of Chicago Press

Attoh K A (2011) What Kind of Right is the Right to the City? Progress in Human Geography 35(5):669-685

Bitter S and Weber H (2009) Autogestion, or Henri Lefebvre in New Belgrade. Berlin/New York: Sternberg Press 
Böhm S, Dinerstein A C and Spicer A (2010) (Im)possibilities of Autonomy: Social Movements in and beyond Capital, the State and Development. Social Movement Studies 9(1):17-32

Bologna S (1991) The Theory and History of the Mass Worker in Italy: Part 1. Common Sense Issue 11 October:16-29

Bologna S (2007) The Tribe of Moles. In, Lotringer S and Marazzi C (eds). Autonomia: PostPolitical Writings (pp 36-61). Los Angeles: Semiotext(e)

Bono P and Kemp S (1991) Italian Feminist Thought: A Reader. Oxford: Basil Blackwell

Bracke M A (2013) Between the Transnational and the Local: Mapping the Trajectories and Contexts of the Wages for Housework Campaign in 1970s Italian Feminism. Women's History Review 22(4):625-642

Brenner N (2001) State Theory in the Critical Conjuncture: Henri Lefebvre's "Comments on a New State Form". Antipode 33(5):753-868

Brenner N and Elden S (2009) Introduction. In Brenner N and Elden S (eds) State, Space, World: Selected Essays/Henri Lefebvre (pp 1-48). Minneapolis: University of Minnesota Press

Brown W (1995) States of injury: Power and freedom in late modernity. Princeton: Princeton University Press

Cantarow E (1976) Abortion and Feminism in Italy: Women Against Church and State. Radical America November-December 10(6):8-28

Castellano et al (1996) Do You Remember Revolution? In P Virno P and M Hardt (eds) Radical Thought in Italy: A Potential Politics (pp.225-238). Minneapolis: University of Minnesota Press:

Charnock G (2010) Challenging New State Spatialities: The Open Marxism of Henri Lefebvre. Antipode 42(5):1279-1303

Cherki E and Wievorka M (2007) Autoreduction Movements in Turin. In Lotringer S and Marazzi C, eds, Autonomia: Post-Political Writings Los Angeles: Semiotext(e):72-79 Cleaver H (1979) Reading Capital Politically. Brighton: Harvester Press Limited 
Coulthard G (2014) Red Skin, White Masks: Rejecting the Colonial Politics of Recognition. Minneapolis: University of Minnesota Press

Cuninghame P (2008) Italian Feminism, Workerism and Autonomy in the 1970s: The Struggle against Unpaid Reproductive Labour and Violence. Amnis. Revue de Civilisation Contemporaine Europes/Amériques (8)

Cuninghame P (2015) Mapping the Terrain of Struggle: Autonomous Movements in 1970s Italy. Available at: https://www.viewpointmag.com/2015/11/01/feminism-autonomism1970s-italy/ (last accessed 14 June 2017)

Dalla Costa M and James S (1972) The Power of Women and the Subversion of Community. London: Falling Wall Press Ltd

Dauve and Martin (1997) The Eclipse and Re-emergence of the Communist Movement. London: Antagonism Press

De Souza M L (2010) Which Right to Which City? In Defence of Political-Strategic Clarity. Interface 2(1):315-333

Dowson E (1973) The Italian Background. Radical America 7(2) March-April:7-14

Federici S (1975) Wages against Housework. Bristol: Power of Women Collective and Falling Wall Press

Federici S (2004) Caliban and the Witch: Women, The Body and Primitive Accumulation. New York: Autonomedia

Federici S (1984) Putting Feminism Back on Its Feet. Social Text 9/10: 338-346

Fortunati L (1995) The Arcane of Reproduction: Housework, Prostitution, Labor and Capital, New York: Autonomedia

Foucault M (1980) Two Lectures. In Power/knowledge: Selected interviews and other writings, 1972-1977. New York: Pantheon Books

Fudge and Glasbeek (1992) 'The Politics of Rights: A Politics of Little Class'. Social and Legal Studies:1:45 
Hardt M (1996) Introduction: Laboratory Italy. In Hardt M and Virno P, eds, Radical Thought in Italy: A Potential Politics. Minneapolis: University of Minnesota Press

Hartman S V (1997) Scenes of Subjection: Terror, Slavery, and Self-Making in NineteenthCentury America. New York: Oxford University Press

Harvey D (1985) The Urbanization of Capital: Studies in the History and Theory of Capitalist Urbanization. Baltimore: The John Hopkins University Press

Harvey D (2008) The Right to the City. New Left Review 53 Sept-Oct:23-40

Harvey D (2012) Rebel Cities: From the Right to the City to the Urban Revolution. London: Verso

Hodkinson S N (2012) The Return of the Housing Question. Ephemera: theory and politics in organization 12(4):423-444

James S (1975) Sex, Race and Class. Available at: https://libcom.org/files/sex-race-class2012imp.pdf (last accessed 19 June 2017)

Lefebvre H (1968) The Sociology of Marx. London: Allen Lane

Lefebvre H (1996) Right to the City. In E Kofman and L Lebas (eds) Writing on Cities.

Oxford: Blackwell Publishing:61-181

Lefebvre H (1991) The Production of Space. London: Wiley-Blackwell

Lefebvre H (2003) The Urban Revolution. Minneapolis: University of Minnesota Press

Lefebvre H (2009) State, Space, World: Selected Essays/Henri Lefebvre. N Brenner and S

Elden S (eds). Minneapolis, MN: University of Minnesota Press

Lotringer S and Marazzi C (2007) Autonomia: Post-Political Writings. Los Angeles:

Semiotext(e)

Lotta Continua (1973) Take over the City - Community Struggles in Italy. Radical America 7(2) March-April:79-112

Lumley R (1990) States of Emergency: Cultures of Revolt in Italy from 1968 to 1978. London: Verso 
Marcelloni M (1979) Urban movements and political struggles in Italy. International Journal of Urban and Regional Research 3(1-4): 251-268

Marx K (1843) Critique of Hegel's Philosophy of Right. Available at:

https://www.marxists.org/archive/marx/works/1843/critique-hpr/ (last accessed 19 June 2017)

Marx K (1844) On the Jewish Question. Available at:

https://www.marxists.org/archive/marx/works/1844/jewish-question/ (last accessed 19 June 2017)

Marx K (1875) Critique of the Gotha Program. Available at:

https://www.marxists.org/archive/marx/works/1875/gotha/ (last accessed 19 June 2017)

Marx K (1993) Grundrisse: Foundation of the Critique of Political Economy. London:

Penguin Classics

Mayer M (2009) The 'Right to the City' in the Context of Shifting Mottos of Urban Social Movements. City 13(2-3):362-374

Macpherson C B (1964) The Political Theory of Possessive Individualism: Hobbes to Locke. Oxford: Oxford University Press

Merrifield A (2011) The Right to the City and Beyond: Notes on a Lefebvrian ReConceptualization. City 15(3-4):473-481

Merrifield A (2013) The Politics of the Encounter: Urban Theory and Protest under Planetary Urbanization. Athens: University of Georgia Press

Mitchell D (2003) The Right to the City: Social Justice and the Fight for Public Space. New York: Guilford Press

Negri A (1987) Archaeology and Project: The Mass Worker and the Social Worker. Common Sense. Issue 3 October:43-71

Negri A (2005) Crisis of the Planner State: Communism and Revolutionary Organisation. In Books for Burning. London: Verso:1-50

Nevins J (2017) The Right to the World. Antipode doi: 10.1111/anti.12324 
Peck J (2012) Austerity Urbanism: American Cities under Extreme Economy. City 16(6): 626-655

Porter L (2014) Possessory Politics and the Conceit of Procedure: Exposing the Cost of Rights under Conditions of Dispossession. Planning Theory 13(4):387-406

Purcell M (2002) Excavating Lefebvre: The Right to the City and its Urban Politics of the Inhabitant. GeoJournal 58(2-3):99-108

Ramirez B (1992) Self-Reduction of Prices in Italy. In Midnight Oil: Work, Energy, War, 1973-1992, Brooklyn: Autonomedia:185-192

Ronneberger K (2009) Henri Lefebvre and the Question of Autogestion. In Bitter S and Weber H (eds) Autogestion, or Henri Lefebvre in New Belgrade. Berlin/New York: Sternberg Press:89-116

Tarrow (1989) Democracy and Disorder: Protest and Politics in Italy, 1965-1975. New York: Oxford University Press

Toscano A (2004) Factory, Territory, Metropolis, Empire. Angelaki: Journal of the Theoretical Humanities 9(2):197-216

Tronti M (1962) Factory and Society. Available at: http://libcom.org/library/factory-society (last accessed 19 June 2017)

Tronti M (1964) Lenin in England. Available at:

https://www.marxists.org/reference/subject/philosophy/works/it/tronti.htm (last accessed 19 June 2017)

Tronti M (1972) The Struggle Against Labour. Radical America 6(1) May/June:22-25

Tushnet M (1984) An Essay on Rights. Texas Law Review 62:1363-1412

Vasudeven A (2015) The Autonomous City: Towards a Critical Geography of Occupation. Progress in Human Geography 39(3):316-337

Williams Jr. R A (1987) Taking Rights Aggressively: The Perils and Promise of Critical Legal Theory for Peoples of Color. Law and Inequality: A Journal of Theory and Practice 5:103-134 
Williams P J (1991) The Alchemy of Race and Rights: Diary of a Law Professor. Cambridge, MA: Harvard University Press

Wright S (2002) Storming Heaven: Class Composition and Struggle in Italian Autonomist Marxism. London: Pluto Press

Žižek S (2009). First as Tragedy, then as Farce. London: Verso

Zukin S (1975) Beyond Marx and Tito. Cambridge: Cambridge University Press 